\author{
3.К. Картова ${ }^{1 *}$ (D) , Б.Е. Көмеков ${ }^{2}$ \\ ${ }^{1}$ М. Қозыбаев атындағы Солтүстік Қазақстан университеті, Қазақстан, Петропавл қ. \\ ${ }^{2}$ Әл-Фараби атындағы Қазақ ұлттық университеті, Қазақстан, Алматы қ. \\ * e-mail:kartov_m@mail.ru

\section{«СЫҒАНАҚ ГРАМОТАААРЫНЫН» $\triangle$ АЕРЕКТАНУАЫҚ ТААААУЫ}

\begin{abstract}
Мақалада ортағасырлық Қазақстан тарихына байланысты деректану ғылымында «Сығанақ, грамоталары» деп аталатын құжаттар кешеніне тарихнамалық талдау жасалған. Формуляр бөліктерін зерттеу, та^дау және салыстыру, XVII ғасырға дейінгі Сырдария маңындағы қалаларда хан жарлықтары берілген деген қорытынды жасауға мүмкіндік береді. Қазақстанның оңтүстік қалаларында - Сығанақ, Сайран, Түркістанда шығарылған төрт жарлықтың екеуі тархандық, біреуі сойюргал, біреу вакуфтық жарлықтары болып табылады. Шын мәнінде, бұл құжаттар нақты түрде тархан жарлықтарының белгілерімен қатар сойюрғал және вакуф жарлықтарымен аралас болып табылады. Бірақ, формулярдағы жеке бөліктері мен сөз тіркестіктері олардың нақты актілік деректерге жататындығын анықтауға мүмкіндік береді. Мақаланың басты маңыздылығы дереккөздердің тарихи интерпретациясында ғана емес, бірегей дереккөздердің эволюциясын анықтауда, жарлықтар формулярларының бөліктерін зерттеуле (Аипломатиялық талдау) және олардың негізінде сыныптауда.

Мақалада көшпелілер өркениетінің жазбаша дереккөздерге пәнаралық зерттеу әдістерін қолдану туралы сипатталады. Жаңа зерттеу әдістерін қолданбай жарлықтардан қажетті тарихи ақпаратты алу мүмкін емес. Сонымен қатар, егжей-тегжейлі деректік талдау ортағасырлық, дереккөздерден А^тын Орда мен Алтын Ордадан кейінгі мемлекеттердің әлеуметтік құрылымы мен жер қатынастары, әлеуметтік-экономикалық дамуы туралы бірқатар құнды мәліметтерді алуға мүмкіндік береді.
\end{abstract}

Түйін сөздер: жарлық, абстракты формуляр, ауызша тарихнама, автохтонды дереккөздер, дипломатика, Алтын Орданың дереккөздері, формулярды қалпына келтіру, тархандық, сойюргал, вакуфтық, жарлық.

\author{
Z.K. Kartova ${ }^{1 *}$, B.E. Kumekov² \\ ${ }^{1} \mathrm{M}$. Kozybaev North Kazakhstan University, Kazakhstan, Petropavlovsk \\ ${ }^{2} \mathrm{Al}-$ Farabi Kazakh National University, Kazakhstan, Almaty \\ *e-mail: kartov_m@mail.ru
}

\title{
Source analysis of «Letters from Sygnak»
}

The article provides a source study analysis of the complex of sources, referred to in source science as «Diplomas from Sygnak». An analysis of the articles of the form allows us to conclude that the khan's labels were issued in the towns near Syrdarya until the 17th century. Of the four labels issued in the southern cities of Kazakhstan - Sygnak, Sairan and Turkestan: two are serving-tarkhan, one is soyurgal, one is vakuf. In essence, these documents contain, in a specific form, mixed elements of the actual tarkhan labels with the soyurgal and vakuf labels. But the combination of individual articles and turns in the form allows you to establish their belonging to specific types of labels. The significance of this study lies not so much in the historical interpretation of sources, but in the collection and identification, disclosure of the evolution of these unique sources based on changes in parts of the labels (diplomatic analysis) and their classification.

The article applies interdisciplinary research methods to the written sources of the nomadic civilization. Extracting historical information from them is impossible without the involvement of new research methods. A thorough source analysis will allow to extract from medieval sources belonging to the Golden Horde and post-Golden Horde states, a number of valuable information about the social structure and land relations of the period under study.

Key words: labels, abstract formulary, oral historiology, autochthonous sources, diplomacy, sources of the Golden Horde, formulary reconstruction, tarhanism, soyurgal, vakuf label. 


\author{
3.К. Картова ${ }^{1 *}$, Б.Е. Кумеков ${ }^{2}$ \\ 'Северо-Казахстанский университет им. М. Козыбаева, Казахстан, г. Петропавловск \\ ${ }^{2}$ Казахский национальный университет имени аль-Фараби, Казахстан, г. Алматы \\ *e-mail: kartov_m@mail.ru
}

\title{
ИсточниковеАческий анализ «Грамот из Сыгнака»
}

\begin{abstract}
В статье проводится источниковедческий анализ комплекса источников, именуемых в источниковедческой науке «Грамоты из Сыгнака». Анализ статей формуляра позволяет слелать вывод, что ханские ярлыки выдавались в присырдарьинских городах почти до XVII века. Из четырех ярлыков, выданных в южных городах Казахстана - Сыгнак, Сайран и Туркестан: два являются служило-тарханными, один - сойюргальный, один - вакуфный. В сущности, эти документы содержат в конкретном формуляре смешанные элементы собственно тарханных ярлыков с сойюргальными и вакуфными актовыми источниками. Но сочетание отдельных статей и оборотов в формуляре позволяет установить их принаАлежность конкретным виАам ярлыков. Значимость Аанного исследования состоит не столько в исторической интерпретации источников, сколько в сборе и выявлении, раскрытии эволюции этих уникальных источников на основе изменения частей формуляров ярлыков (Аипломатический анализ) и их классификация.

В статье применяются междисциплинарные методы исследования к письменным источникам кочевой цивилизации. Извлечение из нихисторической информации невозможно безпривлечения новых исследовательских методов. Тщательный источниковедческий анализ позволит извлечь из средневековых источников, принаАлежащих золотоордынским и послезолотоордынским государствам, ряд ценных сведений о социальном устройстве и земельных отношениях средневекового периода.
\end{abstract}

Ключевые слова: ярлыки, абстрактный формуляр, устная историология, автохтонные источники, Аипломатика, источники Золотой Орды, реконструкция фрормуляра, тарханство, сойюргал, вакуфный ярлык.

\section{Kipicпe}

Алтын Орданың тарихы Орталық Азия мен Шығыс Еуропаның түркітілдес халықтарының тарихи тағдырымен тікелей байланысты. Ақ Орда, Ноғай Ордасы, Сібір, Қазан, Астрахан, Қырым хандықтары құрылуының бастаушысы болған Алтын Орданың әлеуметтікэкономикалық және саяси дамуы, рухани және мәдени өміріндегі мәселелеріне зерттеушілердің қызығушылығы қазіргі кезеңінде өзекті болып отыр. Жаңа әдіснамалық тәсілдер тұрғысынан үрдістер мен оқиғаларды ашатын, бұрын байқалмаған аспектілерді анықтайтын, дүниежүзілік тарихты қайта толықтыратын зерттеулер қажет.

Алтын Орда тарихын дамыту үшін негізінен парсы, араб, қытай және орыс тілдерінде жазылған дереккөздері тартылады. Дереккөздердің бұл кешені деректанулық және тарихнамалық аспектілерде барынша әзірленген және ғылыми ізденістерге кеңінен тартылған. Алтын Орда кезеңінде Оңтүстік-Шығыс Қазақстанға сипаттама беретін дереккөздер арасында деректану ғылымында «Сығанақ грамоталары» деп аталатын құжаттар кешенін бөліп көрсетуге болады.

Бұл жарлықтардың деректанулық талдауы Оңтүстік Қазақстанның көшпелі қоғам дамуының өзіндік заңдылықтарын анықтауға мүмкін- дік береді. Көшпелі мәдениеттегі қалыптасқан дәстүрлер жарлық мәтінінің мазмұнынан көрінбеуі мүмкін емес еді. Жарлықтарда бекітілген құқықтар мен міндеттер көшпелі өмірдің мәнінен, салықтар немесе артықшылықтар тізімінен немесе жер иелену формасынан туындады. Сығанақ, Сайрам және Түркістан жарлықтарында жер иесі мен ауыл қоғамдастығының өзара қарым-қатынасы, оның өкілеттіктерінің шекаралары, сондайақ аграрлық қатынастар тарихына байланысты басқа да мәселелер көрініс тапты. Жерді пайдаланудың әртүрлі нысандары туралы қызықты фактілер, бұл Сығанақ ауданындағы үлкен аймақта жер пайдалану эволюциясының маңызды айырмашылықтары мен ерекшеліктерін анықтауға көмектеседі.

XIV-XVI ғғ. кезеңіндегі көшпелі қоғам өте күрделі болғанын көрсетті, оның өзіне тән ерекшелігі феодалдық қатынастар элементтерінің патриархалдық-рулық тұрмыс нысандарымен үйлесуі болды. Орта Азия өңірі елдерінің жер иелену нысандарын, қазақтардың қарақалпақтармен, өзбектермен, түрікмендермен этномәдени өзара байланысын зерделеу көшпелі қоғамдағы жер қатынастары туралы түсінігімізді едәуір кеңейтер еді, өйткені олар отырықшы егіншілік аудандарынан айтарлықтай ерекшеленетін еді. Жаңа дереккөздер базасын 
анықтау және хан жарлықтар жинақтарын жариялау орта ғасырлардағы кеңсе жұмысының ерекшеліктері мен сипатын ашады, сонымен қатар ортағасырлық кезеңдегі қалалар мен билеушілер арасындағы қатынастардың тарихи көрінісін толықтырады.

\section{Материалдар және әдістер}

В.В.Бартольд 1902 жылы Орта Азияғағылыми іссапары кезінде төрт жарлықтың мәтіндерін табады. Олар 1904 жылы «Императорлық Орыс археологиялық қоғамының Шығыс бөлімінің жазбаларында» аудармасыз қайта жазылып, жарық көрді (Бартольд, 1966: 265-267). Үш грамота түркі тілінде, біреуі парсы тілінде жазылған. «Сығанақ грамоталары» деп аталатын дереккөздер «XV-XVIII ғасырлардағы қазақ хандықтарының тарихы туралы материалдарда (парсы және түркі шығармаларынан үзінділер)» жарияланды (МИКХ, 1969: 317-327). Кеңес тарихнамасында жер иелену тарихын зерттеу үшін жарлықтар А.Ю. Якубовский, П.П. Иванов, В.П. Юдин, А.Е. Ереновтың еңбектерінде дереккөздер ретінде тартылды. Отандық тарих ғылымында олар әлі күнге дейін жеткіліксіз қолданылған.

Барлық ғылымға белгілі жарлықтардың формулярлары төмендегідей тұрақты бөліктерден тұрады: инвокация (діни тұрғыда жазылған бастапқы бөлік); интитуляция (адресант); инскрипция (адресат); нотификация (хабарлама); диспозиция (анықтама); санкция (ұйғарым); короборация (куәлік); эсхатокол (соңғы хаттама). Әрбір жеке алынған құжатқа, хатқа, грамотаға қатысты аталған бөліктердің әрқайсысын жүйелеп қайта құрастыру стилистикалық айналымдар мен палеографиялық зерттеулерді пайдаланумен қатар, ортағасырлық Сығанақ, Сайрам және Түркістан қалаларының тарихына қатысты «жалған жарлықтар» деп аталатын бірқатар деректердің түпнұсқалығын растауға көмектеседі.

XIV-XV ғғ. Моңғолияны, Иранды, сондайақ Орта Азия мен Қазақстан аймағын қамтитын үлкен аумақта сыртқы формуляры мен ішкі мазмұны жағынан өзара өте ұқсас актілік дереккөздер қалыптасады. Бұл ресми актілер бірыңғай үлгі және сыртқы нысан бойынша жасалды, ортақ жалпы абстрактты формуляры құрылды. XIV-XV ғғ. жататын актілік кұжаттарды жіктеуге болады, өйткені мәтіндері мен формулярлары тұрақты рәсімделеді. Хан жарлықтарының жаңа түрлері пайда болады, мысалы, жер иеліктерін растайтын жарлықтар (мульк-наме) және жеңілдіктерді растайтын жарлықтар (мааф-наме). Жеке тұлғалардың немесе қауымдардың жер иеліктеріне құқығын растайтын жарлықтар «иелік жарлығы» деп аталды. Жеңілдік жарлықтары салық-табыс иммунитетін растайтын болды. Тарих ғылымында оларға «тархандық» деген атау бекітілді. Бұл кезеңде жарлықтар ресми іс жүргізу құжаттамасына айналады және осы деректер кешенінің жаңа түрлері пайда болды.

Алтын Ордадан кейінгі кезеңде дереккөздердің формулярында, мәтінінде парсы-араб ықпалы сезінеді. Бұл XV-XVII ғғ. кейбір жағдайда жарлықтардың жекелеген түрлерінің ерте формаларынан алыстап кеткенін дәлелдейді. Біртебірте моңғол формулярлары мұсылманша ауыстырылады, бірақ бұл өзгерістер жарлықтардың шартты түрінің құрылымын өзгертпейді. Мәтіндерінің мазмұны, негізінен, бір дереккөздің өзіндік ерекшелігі мен үстемдігін сақтап, аз ғана өзгерістерге ұшырайды.

Осылайша, Алтын Ордадан кейінгі барлық аймақтарда жарлықтар шығарылды, олар әр түрлі тілдерде жазылды, бірақ құжаттың нысаны мен құрылымы өзгеріссіз қалды. Құжаттар түрінде ортақ белгілер болды.

«Сығанақ грамоталар» деп аталатын деректер кешенін зерттеуінің теориялық-әдіснамалық негізін тарихи зерттеуде қолданылатын әдістердің жиынтығы құрайды. Олардың ішінде жалпы ғылыми әдістер: тарихи, логикалық, индукция және дедукция, талдау және синтездеу әдістері. Актілік дереккөздерін зерттеу терең жүйелі-құрылымдық талдау негізінде жаңа теориялық-әдіснамалық тәсілдер қолдану арқылы жүзеге асырылды. Біздің зерттеуіміздің әдіснамалық негізі тарихи өткенді зерттеуде жүйелілік және этномәдени әдістерді қолдану болып табылады.

Арнайы тарихи әдістердің ішінен тарихи оқиғалар мен құбылыстардың өзара байланысы мен өзара тәуелділігі, тұрақтылық пен дамуды қарастыратын тарихи-салыстырмалы, тарихитипологиялық, жүйелік-құрылымдық әдістер қолданылды.

1. Тарихи-салыстырмалы әдіс XIV-XVI ғғ. актілік дереккөздердің дамуында жалпы және жеке, бірыңғай және ерекше әдістерді салыстыру арқылы анықтауға мүмкіндік береді.

2. Тарихи-типологиялық әдіс хан жарлықтарының топтарын ұқсастығы мен олардың айырмашылықтары бойынша бөлу мақсатында пайдаланылады. 
3. Зерттеуде жүйелік-құрылымдық әдіс әр түрлі аймақтардың белгілерін бірыңғай тұтас кешен ретінде қарастырғанда қолданылады. Бұл әдіс жарлықтарды (актілік дерекөздерді) және бітіктерді (дипломатиялық хаттарды) жаңа тұрғыдан қарастыруға мүмкіндік береді. Дереккөздердің сапалық сипаты мен мазмұнына, формулярлардың жеке бөліктерінің арақатынасына назар аударылады.

\section{Нәтижелер және талдаулар}

1400-1401 жылдардавы Әмір Темірдің тархан-қызметтік жарльвы. Жарлық түркі тілінде жазылған. Орыс тіліне нақтыланған аударма «XVXVIII ғасырлардағы қазақ хандықтарының тарихы жөніндегі материалдарда (парсы және түркі шығармаларынан алынған үзінділер)» жарияланды (МИКХ, 1969: 317-327). Онда Әмір Темір Сығанақ қаласының шайх ал-Ислам қызметіне Сираджа ад-Дин-шайхты тағайындайды және оған тархандықты сыйлайды, Ордакент, Қызылтал, Төмен, Чихил-тоғай елді мекеніндегі Бозғыл-Ұзақ арықтарында әрбір арықта бір-бірден тепе-тен бірнеше жер учаскесін иелік етеді. Оған алымсалықтық иммунитеттің (тархандық) берілуі жарғы мәтінінде мынадай түрде расталады: «және оны барлық жағдайда басқа тархандармен тең, хараж-харажаттан, алықтан, салық пен мердігерден босатылған деп саналсын, (одан) жыл сайын жаңа нишанның паруанашысы талап етілмесін» (Әбусейтова, 2020:152).

Сыр-Дария облыстық басқармасында сақталған жарлықтың мәтінін ғылыми айналымға енгізген В.В. Бартольд (№197 іс) осы құжаттың түпнұсқалығына күмән келтіріп, былай деп жазады: «ең көне құжат 803 (1400-1401 жж.) жатады және Тимурға қатысты; бірақ мұнда Тимурға ешқашан тағылмаған хан атағы берілген және стильдің басқа да ерекшеліктері оның түпнұсқалығына үлкен күмән тудырады〉 (Бартольд, 1966: 268). Одан кейінгі кезеңнің дереккөздерінде кездесетін Сыр-Дария өзені атауының жарлықта қолданылуы да күмән тудырады. В.В. Бартольд XVI ғасырдың екінші жартысында жазылған жалған жарлық деп санаған (Бартольд, 1966: 268). Дегенмен, деректің ғылым үшін маңызы зор екені сөзсіз, өйткені ол ұзақ уақыт бойы ресми құжат ретінде қызмет етті. Бұл құжаттың жалғандығы ешқандай жағдайда оны зерттеу практикасында пайдалану мүмкін емес дегенді білдірмейді, өйткені дереккөздің жариялануының өзі тарих ғылымы үшін өте маңызды.
Дереккөзді ғылыми зерттеулерде кеңінен қолдануға болады, өйткені «осы құжаттың негізінде басқа құжаттар да алынуы мүмкін, ол құжаттың XVI ғасырда нақты күшке ие болғанын айтады, сондықтан терең қызығушылық тудырады» (Бартольд, 1966: 268). Ортаазиялық кеңселерде «мәтіні оқылмайтын ескірген құжаттардың орнына түпнұсқаның орнына олардың көшірмелерін беру дәстүрі» болған (МИКХ, 1969: 315). Мұндай көшірмелер түпнұсқаға сәйкес жасалды, кейбір жағдайларда түпнұсқадан кесілген мөрлер оларға жабыстырылды, бұл, әрине, құжаттың түпнұсқалығына күмән тудыруы мүмкін. В.П. Юдин құжатқа түсініктемелерде және тарихи-деректанулық зерттеулерде: «Мүмкін, Әмір Темірдің жарлығы осындай ауыстыру процедурасынан өткен шығар, ал кейінірек қайта жазған адам Тимурдың шын мәнінде ешқашан оған қатысты қолданбаған хан титулымен атаған екен» (МИКХ, 1969: 318). Зерттеу тәжірибесінде осындай жағдайлар кездеседі, мысалы, 1398 жылғы Тимур-Құтлұқ таңбасының мөрі жоқ, осыған қарамастан, ол ұзақ уақыт бойы Алтын Орда тарихының қайнар көзі ретінде пайдаланылып, зерттелуде.

1543-1544 жылдарындавы Әбу-л-Ғазы Абд ар-Рахым-хан-баһадур сұлтанның тарханқыззметтік жарлызыl. Түпнұсқа, жарлық түркі тілінде жазылған.

Жарлықты алғаш рет В.В. Бартольд 1902 жылы Ташкентте, Сыр-Дария облыстық басқармасында Орта Азияға іссапары кезінде ашқан. «Түркістанға іссапар туралы есеп» атты енбегінде ол 950 ж. (1543-1544 жж.) немесе 955 ж. (1548-1549 жж.) Әбу-л-Ғазы Абд ар-Рахым-хан-баһадүр-Сұлтан Сират-Шайхнақиб берген жарлық мәтінін орыс аудармасыз жариялайды (Бартольд, 1966:270). Оның айтуынша, Сират-Шайх-нақибті Сығанақ қаласының судьясы болып тағайындайды. Оның жарлықтағы лауазымының атауы: «оны куззат әл-ислам және нафиз әл-ахкам етіп тағайындау». Оның міндеттеріне мыналар кірді: «және (ол) заң жолымен, сонымен қатар орындалуы тиіс іске қамқоршының қатысуымен немесе оның қатысынсыз неке қию және некемен қосу ғұрыптарын орындасын, зекетті бөліп тарату (міндетін атқарсын), шариғат бойынша (қаралуға тиіс) барлық істерді (шешсін), араздықты тыйсын деп бұйырдық» (Әбусейтова, 2020:153). Міндеттердің орындалуы оған белгілі бір ақшалай төлемге кепілдік берді: «Ол өзінің ішіп-жемі үшін (неке қию ғұрпын атқарғанда) қыздардан бір тилла, ынсапты әйелдерден жар- 
ты тилла, ажырасқан әйелдерден оннан төрт бөлік тилла алсын». Жарлық мәтінінде тіркелген төлемді көрсету фактісі қызықты болып көрінеді. Мүмкін, бұл Сират-Шайх-нақибтің қаржыны пайдалануының алдын алуы керек еді. Осы өкілеттіктермен бірге Сират-Шайх-нақиб тархан саналады және «Қызыл-Тал арығынан бір тепе жер өңдеу» құқықтары беріледі (Әбусейтова, 2020:153).

Құжатты 955 ж. (1548-1549 жж.) жатқызуға болады, өйткені жарлық мәтінінде соңғы сан өшірілген. В.В. Бартольд бұл белгісіз Абд арРахим хан қазақ ханы болғанын және XVI ғасырдың ортасында Сығанақ Қазақ хандары мен сұлтандарының қол астында болған кезде билік еткенін айтады. Осыған байланысты В.В. Бартольдтың ескертуі: «құжатта аталған Абд-ар-рахим ханы тарихи шығармаларда, менің білуімше, айтылмайды, бірақ ол әлі жоқ деген қорытынды шығаруға болмайды. Сығанақ осы дәуірде, бәлкім, казак хандарының қолында болған, олардың тарихы бізге аз белгілі» (Бартольд, 1966: 271). Бұл құжат қазақ және Орта Азия билеушілерінің жиі ауысуы өзінің әлеуметтік-экономикалық қатынастарын және осы аумақтағы жер иелену нысандарын өзгертпегенін тағы да растайды.

1597-1598 жылдарындавы Әбу-л-zазы Абдаллах-хан-баһадүр сұлтанның сойьрвалдық жарлывы. Түпнұсқа, жарлық парсы тілінде жазылған. П.П. Иванов өзінің «Қарақалпақтар тарихының очерктері» монографиясында алғаш рет аударған, онда қамтылған қарақалпақтардағы феодалдық жер иелену тарихы туралы мәліметтерге талдау жүргізілген (Абусеитова, Баранова, 2001:7). В.П. Юдин «XV-XVIII ғғ. қазақ хандықтарының тарихы бойынша материалдар» жинағына тарихи зерттеулерге кеңінен тарту қажет аударманың жаңа, нақтыланған нұсқасын ұсынды (МИКХ, 1969: 319). Біздің жұмысымызда жарлық мәтіні МИКХ-да жарияланған мәтінінің аудармасы бойынша зерттеледі. Отандық ғылымда жарлық мәтінінің қазақ тілінде аудармасы бар.

1006 ж. (1597-1598 жж.) Абдаллах ханның жарлығы XVI ғасырдың соңына жатады. Оның айтуынша, шайбанид Абдаллах-хан II Сығанақ тұрғындарының иелігіне (Маулан Камал ад-Диннің өтініші бойынша) бірқатар суару арналарын береді. Жарлықта келесі арналар көрсетілген: «Хисаршық бұлағынан басқа Тоқтамыш бұлағы, Хараш бұлағы, Келте-Жалғия арығы, Қызылтал арығы, Арыстанды арығы, Жолақ арығы, Мыңбұлақ арығы....» (Әбу- сейтова, Байтанаев и др., 2020:155). Тұщы құдықтарды, ауыз су көздерін, суару каналдары мен арықтарды жеке меншікке беру тек Оңтүстік Қазақстан қалаларында ғана таралған жоқ. Дәл осындай жарлықты біз Қырым және Казан хандықтарының құжаттарында кездестіреміз.

Сондай-ақ, Хисаршық бұлағы Зийа әд-Диншайх Сығанақ мазарының вакуфтық жер иелігі бекітілген. Бұл бұлақ, ең алдымен, вакуф құқығы бойынша Зийа әд-Дин-Шайхтің діни мекемесіне (мазар) тиесілі болған. Бұл туралы жарлықта былай делінген: «өйткені аталған Хисаршық - рахмет алла гәләйһ, - Хазірет Аллама Әбу-л-хасан Зийа әд-Дин-Шайха Сығнақи мазарының уакфына қаратылған» (Әбусейтова, 2020:155).

Жарлықтың адресатында басқа тайпалармен қатар қазақтар туралы да айтылады: «ауылдарда (тұрақты), қышлақтарда (жартылай отырықшы) тұратындарға, көшпелі өмір сүруші адамдарға, лауазымды адамдарға, арабтарға, түркілерге, қазақтар мен қарақалпақтарға мәлім болсын» (Әбусейтова, Байтанаев и др., 2020:155). Осылайша, жарлықта біз XVI ғасырда жерге феодалдық қатынастардың дамуына ықпал еткен көшпелі шаруашылық-мәдени типтің эволюция үдерісі жалғасатынын растаймыз. Н.Э. Масанов «осы негізде көшпенділер ортасында отырықшы-егіншілік аудандарға қатысты шаруашылық-мәдени қарсылық идеологиясы туындайды» деп болжайды (Kumekov, Kartova, 2019: 20). Көшпенділердің егіншілік ауданға келуі қашанда егін шаруашылығы мен көшпелі халық мүдделерінің қақтығысына әкеп соққаны белгілі: мұнда кейде егістік, суармалы жерлер айналысатын жайылымдарға арналған жерлердің жетіспеушілігі және көшпенділердің қажеттілігі қашанда болған қолөнер мен егіншілік өнімдерін жергілікті халықтан тікелей алып қою да орын алған. Көшпелі және егіншілік халықтың мүддесіндегі бұл қарама-қайшылық Абдаллах ханның 1597-1598 жылдардағы жарлығында көрініс тапты, оның берілуі жергілікті сығанақтық жер иесінің өтініші бойынша «көшпелі тайпаларымыз (илатаийа майан) оның (Маулана Камал ад-диннің) арықтары бойындағы жерлерге нұқсан келтіргені» деген шағыммен туындады (Әбусейтова, 2020:154).

1634-1635 жылдарындавы Әбу-л-вазы Ұбайдаллах-хан-баһадүр-сұлтан вакуфтық жарлызы. Түпнұсқасы, жарлық түркі тілінде жазылған. 1044 жылы (1634-1635 жж.) Ұбайдаллах хан атынан берілген бұл жарлық Сырдария маңындағы қалалардың тарихына қатысты акт көздері ішіндегі ең соңғы құжат болып та- 
былады. Жарлық Ташкент, Түркістан және Сырдариядағы басқа да қалалар үшін Бұхара ханы Имам Құлы мен қазақ сұлтандары арасында тұрақты соғыс болған кезеңде жазылған. В.В. Бартольд бұл хатты 1628 жылы Есіл хан (Есім хан) қайтыс болғаннан кейін Ташкенттің билеушісі етіп тағайындаған Бақи Мұхаммед ханның ұлы Абдаллах хан жазған деп болжайды. «Ең болмағанда, - деп жазады ол, - сол кездегі қазақ хандары мен сұлтандарының арасында Махмуд б. Вели, Обейдаллах ханның аты жоқ» (Бартольд, 1966: 273).

«XV-XVIII ғғ. қазақ хандықтарының тарихы жөніндегі материалдарда» Махмұд ибн Уәлидің Ұбайдалла-хан атындағы қазақ сұлтандарының болмауы, олардың арасында мұндай атаумен ханның болуы мүмкін емес дегенді білдірмейді. В.В. Бартольдтың еңбектерінен кейбір қазақ, сондай-ақ түркі, хандар түркі аттарымен қатар араб тектес «мұсылман» есімдерінің болғанын көруге болады. Мысалы, Қазақ хандығының негізін қалаушылардың бірі саналатын Жәнібек хан «өзінің түркі атымен қатар араб тектес Әбу Сағид немесе Бу-Сағид есімін алған» (Бартольд, 1966: 273). Бұл туралы басқа ақпарат көздерінде бірнеше рет көрсетілген. Осындай бақылауды кейбір басқа хандарға қатысты да жасауға болады. МИКХ авторлары «Ұбайдаллах-ханБаһадур-сұлтан - Абдалла-сұлтан Махмұд ибн Уәли емес, оның соңғы автордың шығармасында өзінің кең таралған қазақи есімімен кездесетін қазақ сұлтаны деген болжам жасауға болады. Араб құжаттарының ресми атауы заңды құжаттарда колданылған деп болжау заңды» (МИКХ, 1969: 362).

Жарлық нақты формулярының баптарын бөліп көрсету принципіне негізделген жарлық мәтінін деректанулық талдау және барлық төрт мәтінін құрудың жалпы схемасы олардың Алтын Орда жарлықтарының ұқсастығын анықтауға мүмкіндік береді.

Бастапқы формула, инвокация және интитуляция (адресант) жарлықтардың нақты формулярының жалпы қабылданған бөліктеріне сәйкес келеді, барлық төрт грамотада олар Алтын Орда құжаттарына ұқсас құрастырылған. Жарлықта интитуляцияда «біздің сөзіміз» және корробацияда «нишан» қатар қолданылады. Бұрын «менің сөзім (біздің сөзіміз)» термині бар адресат жарлықта немесе хабарлама жарлықтарында (битике) қолданылуы мүмкін екендігі айтылған. Бастапқыда парсы тілінде жазылған Әбу-л-ғазы Абдаллах-хан-баһадүр-сұлтанның жарлығы ұлы хандардың белгілері үшін қабылданған екі жолды кіріспемен сипатталады. Онда ханның ауызша бұйрығы, оның бұйрығы - белгі Мәңгілік Кұдайдың күшімен және оның қамқорлығымен күшейтілетіні көрсетілген. Жарлықта: «ол мәңгі өмір сүреді! Әбу-л-ғазы Абдаллах-хан-баһадүр-Сұлтан, біздің сөзіміз». Орыс митрополиттеріне берілген хан белгілеріне ұқсас: «Құдайдың құдіретімен жоғарғы троица Менгу Тимурдың сөзі» (Григорьев, 2004:352).

Негізінде, жарлық адресаттарының құрамы Алтын Орданың бүкіл өмір сүру кезеңінде ғана емес, сонымен бірге ол ыдырағаннан кейін де өзгерген жоқ. Адресаттар бұл белгілердің иелеріне хандардың берген құқықтарын жүзеге асыру сол немесе басқа дәрежеде байланысты болған адамдар. Менгу-Тимурдың (1267 ж.) ең алғашқы жарғылардың бірінің үзіндісін келтірейік: «Мәңгілік Құдай күш, біздікі, Менгу-Тимур, қалалар мен ауылдардың даругакнязьдеріне, әскер князьдеріне, хатшыларға, кеденшілерге, елшілерге, сұңқарлар бапкерлеріне және аң аулаушыларға» (Григорьев, 2004:352). Салыстыру үшін кейінірек 1398 жылғы ТимурҚұтлығтың жарлығында: «Оң және сол қанаттың Огландарына... Мың, жүз, он мыңдықтар, қазыларға, муфтиям, шейхтер, сопылар, палата жазушылары, алым жинаушылар, кеденшілер, жолшылар, букаул, туткаул, ямщиктер, базар бақылаушыларына...» (Радлов,1888: 23).

Зерттелген жарлықтар адресаттар тізімі біршама кеңірек, мысалы, Әбу-л-ғазы Ұбайдаллахан-баһадүр-сұлтанның 1044 ж. (1634-1635 жж.): «саййидтерге, ұлы діндар-ғалымдарға, жігерлі ғалым қайраткерлерге, мәртебелі әмірлерге, қадірлі қазыларға, шайхтар мен даналарға, сонымен қатар ізгі текті арбабтарға, барлық үлкенкіші кадхудайларға мен қожа (және) шарик (санатындағы) раиййаттарға мәлім болсын.....» (Әбусейтова, 2020:156).

Кейінгіжарлықтамұсылмандінбасыларының (казылар, шейхтер, мүфтилер) өкілдерін атап өтуі исламның қабылдануын және мұсылман институттарының Орда құқығы жүйесіне қосылуын көрсетеді. Діни қызметкерлерден басқа, әскери-феодалдық ақсүйектер, сондайақ азаматтық әкімшілік өкілдері ортағасырлық қоғамның әлеуметтік құрылымының маңызды құрамдас бөлігі болды. Бұл жарлықтарда аталған жүзбегі мен мыңбегілер болды. Орталық және жергілікті әкімшілік өкілдері мен шенеуніктердің арасында әртүрлі лауазымды тұлғалар, аудандар мен жекелеген облыстардың билеушілері, салық жинау жөніндегі шенеуніктер аталған. 1597-1598 жж. Әбу-л-ғазы Абдалла-хан-бахадур 
сұлтан жарлығында: «...құрметті әмірлерге, ұлық арбабтарға, мыңбегілерге, жүзбегілерге, мирхазарларға, раийаттларға, (жергілікті) тұрғын жамағаты мен (сол жерде) тұратын бәріне...» (Әбусейтова, 2020:154).

Олардың барлығы шартты түрде берілетін немесе тұрғындардан жиналған салықтар есебінен қомақты жер телімдеріне ие болды. 1598 жылғы жарлықтарда бірқатар ауыз су көздері мен бірнеше арықтар «Сығанақ тұрғындарының мүлкісі» деп аталды (Әбусейтова, Байтанаев и др., 2020:154). Алайда, қол жетімді мәліметтер негізінде осы мүліктердің мөлшерін, олардың жеке ірі жер иелеріне немесе қауымдастыққа тиесілі екенін нақты анықтау мүмкін емес.

Аймақтардың билеушілері немесе вассал мемлекеттеріндегі өкілдер (Ресейде «баскаки» деп аталады) тиісті облыстарда немесе вассал мемлекеттерінде тұратын адамдарға белгі берілген кезде кездесті. Сондықтан, барлық ерте жарлықтарда кездесетін Алтын Ордадағы әскери элитаның мағынасына байланысты «әскерлердің князьдеріне» немесе «оң және сол қанаттардың оғландарына» деген сілтеме жасалмайды.

Бір қарағанда, «ұлық арбабтар» және «ұлы діндар-ғалымдар» сияқты адресаттардың кездесуі ерекше таңқаларлық. Атаулардың өздері бұл шенеуніктердің істеген қызметтерін көрсетеді. Сондай-ақ, адресаттардың қатарына «қожа (ходжа) және шарик» деген анықтама қосуы ерекше болып көрінеді. Олар зерттелген жарлықтардың үшеуінде кездеседі. П.П. Иванов бұл терминді келесідей аударды: «ходжалардан (жерлерді) жалға алатын шаруалар» және осыған сүйене отырып, ходжалардың жер иелігінің Сығанақ аймағында кеңінен қолдану туралы тұжырым жасады, бұл дәлелді факт болуы мүмкін. Бірақ В.П. Юдин бұл терминді «раиййаттар, (санаттарға жататын) ходжа мен шарик» деп аударады, шаруаларды екі топқа бөледі: ходжа - жер иелері және шарик - жалға алушылар (МИКХ, 1969: 318). МИКХ авторлары «осы сөз тіркесінің стандартты сипатына, оны бірқатар басқа құжаттарда қолдануға» сілтеме жасай отырып, П.П. Ивановтың болжамының дұрыс еместігін көрсетеді және бұл терминді «ходжа мен шарик санаттарына жататын раиййаттар» деп аударады. Бұл жерде «ходжа» тікелей өндірушіні, шаруашылықты өз бетінше жүргізушіні - иесін, ал шарик баспагерді білдіреді» (МИКХ, 1969: 318-319). Мұндай адресаттың қосылу себебін түсіну үшін осы кезеңдегі жер иелену формаларын есте ұстаған жөн. Бұл жерде біз А.П. Григорьевтің тұжырымдарымен толық келісеміз: «алайда, мұндай салыстыру, XIII ғасырдың ортасындағы оқиғаның бастапқы мазмұнын қайта құру қажеттілігін тудырған оқиғалар орын алған аумақта болған нақты фактілерін түсінгеннен кейін жүргізілуі тиіс» (Григорьев, 2004: 251). Жарлықтардың барлық бөліктерін сәйкестендіру және мәтінді қайта құру болашақ зерттеулерге кеңінен мүмкіндік береді.

Осылайша, Сығанақ уәлаятының хан жарлықтарының адресаттары Оңтүстік Қазақстан аумағында әкімшілік қызметтерін жүзеге асырған барлық қадірлі адамдар мен шенеуніктер болды. Бірақ бұл аппарат үнемі өзгеріп отыратындықтан, хандар көбінесе белгілі бір адресаттарды тізімдеп, олардың тізімін «барлығына» деген сөзбен аяқтады. Бұл, бір жағынан, жарлықты беру кезінде әлі болмауы мүмкін лауазымды тұлғалардың хандық бұйрықтарын орындаушылардың қатарына қосу үшін жасалды. Екінші жағынан, адресаттардың ауқымы едәуір кеңейе түсті, өйткені оған тек шенеуніктер ғана емес, сонымен қатар жарлық иелері тұрған немесе жай тұрған аумақтардың қалған тұрғындары да кірді. Мұндай жағдайда адресаттардың тізімін кең етіп жасады және оны кез-келген адам орындауға тиісті болды.

Шенеуніктердің іс жүзінде толық тізіміне қарамастан, мемлекеттік және әкімшілік құқық тарихында дереккөздер ретінде жарлықтарды жартылай ғана пайдалануға болады. Р.Ю. Почекаев «олар (жарлықтар - 3.К.) осы аппаратты қандай шенеуніктер құрғанын анықтауға, оның мемлекет өмір сүрген уақыт ішінде қалай өзгергенін бақылауға мүмкіндік береді, бірақ олардың функционалдық міндеттері мен Алтын Орданың әкімшілік аппаратының құрылымдық иерархиясына толық түсіндірмейді. Біз қандай да бір лауазымды адамның мәртебесі туралы қосымша мәліметтерді қосымша дереккөздерді, оның ішінде тек Алтын Орданың ғана емес, басқа да Шығыс мемлекеттерінің (атап айтқанда - Бағдад халифаты, Қытай, Түркі мемлекеттері және т. б.) тарихы бойынша дереккөздерді тарта отырып қана аламыз» (Pochekaev, 2019: 5). Сонымен бірге, тарихи дереккөз ретінде жарлықтардың адресаты діни иерархия мен қоғамның әлеуметтік стратификациясы туралы қорытынды жасауға мүмкіндік береді.

Жарлықтар диспозициясының негізгі тұстарын талдау нәтижесінде, барлық жарлықтарда босатылатын салықтардың, салық-баждардың тізімі өте ұқсас деп айтуға негіз береді. Мысалы, 1400-1401 жж. жарлықта оқимыз: «Аталған 
уәлаттың барлық шайхтары (мен) ізгі текті білімдар арбабтары (оған) лайықты сый-құрмет көрсетсін және қадір тұтсын; ол өзінің ішіпжемі үшін Ордакент арығынан бір тепе жерді, Қызылтал арығынан бір тепе жерді, сонымен қатар Сырдариядан шыққан Төмен арықтан бір тепе жерді, Бозғыл-Ұзақ арығындағы ЧихилТоғайдан бір тепе жерді өңдесін. Және ол қаржылық-салық тізімдерінен босатылған тархандар қатарындағы тархан саналсын, барлық жағдайда басқа тархандармен тен, хараж-харажаттан, алықтан, салық пен мердігерден босатылған деп саналсын, одан жыл сайын жаңа нышанның паруанашысы талап етілмесін» (Әбусейтова, 2020:152). Шығарылған уақыты бойынша ең кейінгі 1634 жылғы жарлықта диспозициялық мақала өзгеріссіз қалды: «.... сондай-ақ (олар) қаржылық-салық тізімдерінен шығарылған тархандардың қатарындағы тархан саналсын, сондай-ақ (олар) барлық жағдайда (басқа тархандармен) тең саналсын және харжхаражаттан, мал-и жихадта, алық-салықтан, мердігерден, қоналғы мен жамылғыдан босатылсын. Осы нышанды көріп (оларға) ежелгі дәстүр бойынша тойлар мен бата қылу салттарында (асқа қатысқандар арасында бұлжымас дәстүр бойынша бөлінетін мал етінен) сыбағасы берілсін және олардан жыл сайын жаңа паруанашысы талап етілмесін» (Әбусейтова, Байтанаев и др., 2020:154). Осылайша, шартты формулярдың бұл бөлігі Сығанақтың барлық жарлықтарында кездеседі және іс жүзінде Алтын Орда мен Қазан хандықтарының жарлықтарынан ерекшеленбейді. Біз харадж-хараджат, алық және салық сияқты салықтарды ертерек жарлықтарда кездестіреміз (Aksanov, 2017: 211).

1400, 1543 және 1634 жылдардағы жарлықтарда бұрынғы кезеңнің деректері бойынша белгілі харж салығы туралы айтылады (жер салығы - харж-харажат, парсы тілінен - шығын, ысырап). Мүмкін, бұл күрделі термин салықтарды да, алымдарды да, жалпы және жеке түрлерін де білдіруі мүмкін. Осы жарлықта «алық ва салық» термині келтіріледі; А.А. Семеновтың пайымдауынша, «бұл термин салықтарды, жалпы салық төлеуді білдіреді» (Почекаев, 2004:140). Жарлықтағы осы алымдар мен салықтардың мөлшері белгісіз. Атап айтқанда, Рузбехан қазақтарға жорыққа аттанған Шайбани ханның әскері үшін «Түркістанның шығыс аудандарында» ондаған мың әскерге айлық үлес жиналғанын айғақтайды (Усманов, 1979: 222). Бұл үлкен армия қанша азықтүлік пен жем-шөпті талап еткенін елестете аласыздар.
Убайдаллах ханның 1634 жылғы жарғысында тағы бірнеше салық түрлері аталған. Мал-и джихад салығын В.В. Бартольд «(қалмақтармен) діни сенім үшін соғысқа ақша» деп анықтайды В.П. Юдин 1617 жылғы Имам-Құли ханның сойюргальды жарлығына түсініктеме бере отырып, «В.В. Бартольд бұл үзіндіде хат мәтінін дұрыс оқымаған және жариялаған болуы мүмкін, мүмкін бұл «хараж» терминінің синонимі (Бартольд, 1966: 266). Сонымен бірге, 1543-1544 жж. Әбу-л-ғазы Абд ар-Рахим хан-бахадүр-сұлтан және 1634 жылғы Әбу-л-ғазы Убайдаллаххан-бахадүр-сұлтан жарлықтарында салықтан босатудың жаңа түрі пайда болады, бұл артықшылыққа ұқсас: «(оларға) ежелгі дәстүр бойынша тойлар мен бата қылу салттарында (асқа қатысқандар арасында бұлжымас дәстүр бойынша бөлінетін мал етінен) сыбағасы берілсін» (Әбусейтова, 2020:153). Бұрын ешқандай жарлықта біз мұндай артықшылықты кездестірген жоқпыз. Көшпелі және отырықшы халықтардың өзара қарым-қатынасы, көшпелі мәдениеттегі қалыптасқан дәстүрлер дереккөздердің мазмұнына әсер етіп, олардың мәтініне қоғамның әлеуметтік-экономикалық және саяси құрылымының ерекшелігін енгізді.

Көріп отырғанымыздай, салықтың жекелеген атаулары өте тұрақты болды және бірнеше ғасырлар бойы сақталды. В.В. Григорьев атап өткендей, бұл тек кеңсе терминологиясының тапшылығында және «көшпелі тілдердің кедейлігінде» ғана емес. Түсіндірмені көшпенділердің өндірістік қызметін сол кездегі қоғамның тыныс-тіршілігін қамтамасыз ету жүйесі ретінде ұйымдастырудың дәстүрлілігінен, Алтын Орда және одан кейінгі елдердің әлеуметтікэкономикалық құбылыстарының ортақтығынан іздеу керек. Бұл жағдайда біз М.А. Усмановтың пікірімен келіспейміз, ол 61 ҚазанҚырым жарлықтарының формулярларын зерттей отырып: «XVI ғасырдың ортасы мен екінші жартысындағы таңбалардағы бірқатар салық терминдерінің толық жойылуы дәстүрлі джучидтердін салық институттарының белгілі бір бөлігінің осы кезеңге ескіргенін көрсетеді» (Усманов, 1979:231).

Сонымен, жарлықтардың диспозициялық мақаласында Оңтүстік және Оңтүстік-Шығыс Қазақстанның егіншілік аудандарының әртүрлі салықтары мен міндеттерін белгілеу үшін қызмет ететін маңызды терминологиялық материал қамтылған. Соңғысы өте құнды, өйткені аграрлық жүйеге сәйкес осы құжаттардан басқа отандық тарихнамада тек үзінді, бірыңғай ақпарат сақталған. 
Дипломатиялық талдау санкция шартты формулярдың құрамдас бөліктерінің бірі болып қала берсе де, елеулі өзгерістерге ұшырағанын көрсетеді. Мысалы, бұл жарлықтарда 1381 жылғы Тоқтамыс немесе 1398 жылғы ТимурҚұтлұқ сияқты міндетті және шектеуші санкциялар жоқ. Хаттарда тек - клаузула бөлігі бар. 1543-1543 жж. Әбу-л-ғазы Абд ар-Рахим хан-бахадүр-сұлтанның жарлығында санкция: «Енді осы нышанды көргенде жоғарыда аталған адамға жүгініп, (біздің әмірімізді) бүгіп жасырмай, лайықты құрмет көрсетіп қошеметтесін, оның заңды әрі ізгі текті шешімдерінен аттамасын». 1634 жылғы Әбу-л-ғазы Убайдаллах-ханбахадур-сұлтанның жарлығында: «олар алдағы уақытта біздің басқаруымызда тыныштыққа шақырушылар болып қалсын, аталған уақфты пайдалануға ешкім килікпесін, кедергі келтірілмесін» (Әбусейтова, 2020:153).

Барлық зерттелген жарлықтар «нишан» деп аталады, яғни түркі тілінде жазылған үш жарлық түпнұсқасында: «бұл пәтуалы нишан» деп жазылған. «Нишан» сөзінің ежелгі мағынасы бар: 1) белгі, белгі, із, белгі, із; 2) құжаттағы жеке белгінің мөрі, бедері (Kurat N. Akdes, 2001: 26). Екінші мағынада бұл сөз 1347, 1351, 1354 жылдардағы Тайдула ханшайымының жарлығында қолданылады. Алтын Орда жарлықтарының формулаларындағы «алтын нишан» формуласы пайцзенің орнына келді және «сақина мөрі» мағынасында қолданылды (Григорьев, 2004: 33).

Барлық Қазан және Алтын Орда жарғыларында «нишан», «тамға», «мухр» терминдері бірдей мағынаға ие бола отырып, «мөр» ұғымында қолданылды (Nasan Bayar, 2014: 245). Мысалы, 1347 жылғы Тайдуланың «нишан жарлығы», «нишанмен бірге жарғы берілді» (1468 жылғы 11 шілдедегі Менгли Гирайдың тархан жарғысында немесе 1468 жылғы 30 қыркүйектегі Менгли-Гирайдың сойюргальды жарғысында). Дегенмен, «нишан» сөзінің негізгі мағынасы - мөр, бұл жарғыларда кездесетін терминдер: «алқызыл нишанмен», «сақиналы нишанмен» және т.б. (Nasan Bayar, 2014: 245). М.А. Усманов «бұл термин XII-XIII ғасырлардағы ұйғыр іс жүргізу тәжірибесінен алынған, ол ерте парсы тілінен алынған» деп көрсетеді (Усманов, 1979: 234) «Нишан» термині парсы тілінен аударғанда «хан жарғысы». Демек, жарлықтардың корроборациясында «жарғы» мағынасында қолданылған «пәтуалы нишан» термині дәл емес аударма нәтижесінде, немесе парсы және түркі тілдеріндегі жалпы қабылданған канондардың әсерінен пайда болды (A. Melek Özyetgin, 1996).

Жарғылардың соңғы хаттамасының баптары белгілі бір өзгеріске ұшырағаны байқалады. Барлық жарғыларда берілген күні болады, бірақ берілген жері көрсетілмейді. Ерте жарлықтарында соңғы хаттамада хан ордасының орналасқан жері көрсетілген. В.Д. Смирнов «жарлықтардағы белгілерге сүйенсек, хан ордасы үнемі бір орыннан екінші орынға ауысады, бұл жалпы көшпелі қоғамның мәнінен туындайды» деп атап өтті (Кушкумбаев, 2020: 15). Зерттеген жарлықтарға келсек, ең алдымен, оларды бір жерде шығарылды, таралу аймағы тек «Сығанақ вилайеті» болды. Вилайет (әкімшілік бірлік) аумағының шекарасын анықтау, кеңсе мен кеңсе жұмысы тарихының көптеген мәселелері жеке зерттеуді талап етеді.

\section{Қорытынды}

«Сығанақ жарлықтарының» шартты және нақты формулярларын зерттеу және деректанулық талдау бірқатар маңызды тұжырымдар жасауға мүмкіндік береді:

1. «Сығанақ грамоталары» деп аталатын барлық актілік дереккөздер жарлық болып табылады.

Әбул-ғазы Әмір Темір-хан-бахадур-сұлтан 1400-1401 жылдарыберілгенграмота-қызметтіктархандық жарлық. Жарлықта «қадір-қасиеті ерекше биік, шариғатқа жетік Сираж әд-диншайхтың шариғатты білуімен ерекшеленетін, жоғары қадір-қасиетімен ерекшеленетін Сираж ад-Дин-шейх ғұмырлық жағдайларға келбеті мен үмітті жүзінде бізге шапағат тілеген тілектестік бейнесі мен өнегелі мінез нышаны анық та айқын көрініп тұратыны мәлім. Біз осының негізінде оған біздің хандық жебеуміз бен біздің хандық мейірімізді сыйлап, өзінің қызметін атқаруға тәуелсіз шайх әл-ислам қызметіне лайық көріп әмір еттік» (Әбусейтова, 2020:153). Шейх-әлислам тағайындаған жерлерді «өзінің ішіп-жемі үшін» тиіс деп берілген жер иелігінің сипатына ие емес, өйткені бұл артықшылық діни лауазымды адал атқарғаны үшін төлем ретінде берілген. Сондай-ақ, жер сойюрғалды жарғы мұрагерлік меншікке бекітілмеген.

1543-1544 жылдары Әбу л-ғазы Абд арРахим-хан-бахадур-сұлтан берген екінші жарлық қызметке тағайындауға берілген қызметтіктархандық жарлық болып табылады. Мұнда бұл лауазым куззат әл-ислам және нафис әл-ахкам деп аталады. «Ислам казиясы» деген терминнің 
тура аудармасы «лауазым» дегенді білдіреді, екінші терминнің мағынасы «шешімдерге әсер ету» деп аударылады. МИКХ авторлары бұл терминді екі лауазымдық қызмет деп аударады. Казийдің (судьяның) бір лауазымы туралы айтып отыра, оның қызметтеріне үйлену рәсімдерін жүргізу және мұсылман заңдарын сақтау жатады деген. Сонымен қатар, куззат ал-ислам «зекетті таратып, шариғат бойынша барлық істерді шешіп, араздықты тоқтату» істерімен айналысқан (Әбусейтова, 2020:154). Оған басқа да артықшылықтар беру, оның ішінде салықтық иммунитет «куззат әл-ислам және нафиз әлахкама» (судья) әлеуметтік мәртебесімен байланысты.

Әбу-л-ғазидің Абдаллах-хан-бахадурсұлтанның 1597-1598 жылдардағы берілген грамотасы - сойюргалды жарлық болып табылады. Жарлықта Сығанақ тұрғындарының тұщы су көздері мен каналдарға құқықтары бекітілген. «Біздің [көшпенді] тайпалар оның [Мәулан Камал ад-Дин] каналдарының бойында орналасқан жерлерге зиян келтіреді», - деп сойюргалдың Сығанақ қаласының қауымына белгі беріп, бекітуіне себеп болды (Әбусейтова, 2020:154). МИКХ авторлары сойюргальды жарғы Маулан Камал ад-Динге тиесілі деп санайды. Бірақ айналымның диспозициясында «Сығанақ тұрғындарының мүлкісі» деген сөз Сығанақ қауымдастығының сойюргальдік құқығы жарғыда бекітілген деп айтуға мүмкіндік береді. Садр-алисламның лауазымын атқарған Маулан Камал ад-Дин қоғамның өтінішін білдіруге құқылы болды.

1634 жылы Әбу-л-ғазы Убайдаллах-ханбахадур-сұлтан берген төртінші жарғысы - уакыф (вакуф) жарғысы. Онда бекітілген жерлер мен иеліктердің шекараларын анықтаумен қатар, Сығнаки мазарының уақыфына Хисаршық бұлағын беру туралы беру және пайдалану туралы айтылған (Әбусейтова, 2020:154). Осыған сүйене отырып, Хисаршық арығы діни қауымдастықтың иелігіне айналады.

2. Формулярдың баптарын талдау жарлықтардың барлық түрлері XVII ғасырға дейін Сырдария маңындағы қалаларда берілген деген қорытынды жасауға мүмкіндік береді. Шын мәнінде, жарлықтар тарихи дереккөздер түрі ретінде ортағасырлық хандықтар мен Сырдария маңындағы қалалардың іс жүргізу тәжірибесінде қолданылған деп айтуға болады. Қазақстанның оңтүстік қалаларында берілген төрт жарлықтың екеуі тархан, біреуі сойюргал, біреуі вакуф жарлықтары болып табылады.
Шын мәнінде, бұл құжаттар нақты формулярда тархан жарлықтарының сойюргальды және вакуфті аралас элементтерін қамтиды. Бірақ формулярдағы жеке клаузулар, мақалалар мен баптары олардың белгілі бір жарлық түрлеріне жататындығын анықтауға мүмкіндік береді.

3. Алтын Орда кезеңінен кейінгі актілік деректер өз формулярында парсы-араб әсерін қамтиды. Моңғол тіліне тән формулаларын мұсылман дәстүріне ауыстыру біртіндеп жүруде, бірақ бұл үрдістер жарлықтардың шартты және дерексіз формулярының құрылымын өзгертпейді. Жарлық мәтіндерінің мазмұны аз ғана өзгерістерге ұшырайды, тұтастай алғанда бастапқы дереккөздердің құрылымын сақтайды.

Осылайша, жарлықтар солтүстік-шығыстан кейінгі барлық аумақтарда шығарылды, олар әртүрлі тілдерде жазылды, бірақ құжаттың нысаны мен құрылымы өзгеріссіз қалды. Құжаттардың формулярларында ортақ белгілер болды.

4. Бұл құжаттар тарихи өте ұзақ кезеңді қамтиды (XIV-XVII ғасырлар) және олар ортағасырлық феодалдық қоғамға тән құбылыстарды бейнелейді. Аталған жарлықтардың барлығы Сайрам, Түркістан және Сығанақ Орта Азия хандарының қол астында болған уақытқа қатысты болды. Бұл ортағасырлық қоғам тарихына қатысты көптеген мәселелерді жан-жақты зерттеуге, пайда болу кезеңінен бастап тарихи аренадан жойылғанға дейін әртүрлі феодалдық институттарды зерттеуге мүмкіндік береді. Құжаттарда көптеген географиялық атауларды атап өту құнды, бірақ, өкінішке орай, жарлықтардың топонимикалық деректерін зерттеушілер толық пайдаланбаған.

5. Жарлықтардың деректанулық талдауы Оңтүстік Қазақстанның көшпелі қоғамы дамуының өзіндік заңдылықтарын анықтауға мүмкіндік береді. Көшпелі мәдениеттегі қалыптасқан дәстүрлер жарлық мәтінінің мазмұнына әсер ете алмады. Жарлықтарда бекітілген құқықтар мен міндеттер өмірді қамтамасыз етудің көшпелі формасының мәнінен, салықтар немесе артықшылықтар тізімінен немесе жер иелену формасынан туындады. Сығанақ, Сайрам және Түркістан жарлықтарында жер иесі мен ауыл қоғамдастығының өзара қарым-қатынасы, оның өкілеттіктерінің шекаралары, сондайақ аграрлық қатынастар тарихына байланысты басқа да мәселелер көрініс тапты. Сығанақ вилайеті (әкімшілік бірлік) үлкен аймақтағы жерді пайдалану эволюциясының маңызды айырмашылықтары мен ерекшеліктерін анық- 
тауға көмектесетін жерді пайдаланудың әртүрлі түрлеріне қатысты қызықты тарихи фактілер бар.

XIV-XVI ғғ. кезеңіндегі көшпелі қоғам өте күрделі әлеуметтік құрылым болды, оның өзіне тән ерекшелігі феодалдық қатынастар элементтерінің патриархалдық-рулық тұрмыс нысандарымен үйлесуі болды. Орта Азия өңірі елдерінің жер иелену нысандарын, қазақтардың қарақалпақтармен, өзбектермен, түрікмендермен этномәдени өзара байланысын зерттеу көшпелі қоғамдағы жер қатынастары туралы біздің түсінігімізді едәуір кеңейтер еді, олар отырықшы егіншілік аудандарынан айтарлықтай ерекшеленетін еді.

XIV-XVI ғасырлар кезеңіндегі Қазақстанның оңтүстік-шығысын сипаттайтын дереккөздерде қоғамның бүкіл салық жүйесі туралы мәліметтер жеткіліксіз, ұсақ қолөнершілер, саудагерлер және т.б. категориялары туралы мәліметтер а3. Соған қарамастан, қол жетімді материал, әсіресе жер меншігімен және жалпы әлеуметтікэкономикалық өмірмен байланысты оқиғалар мен құбылыстарды тарихи қайта құруды едәуір кеңейтеді. Отырықшы ауылшаруашылық және көшпелі малшы компоненттерінің синтезі әлеуметтік-экономикалық дамудағы меншік пен құбылыстардың жаңа формаларының пайда болуын, экономикалық қызмет құрылымы мен әлеуметтік стратификацияны талап етті. Жарлықтарға сәйкес, көшпелі өмір салтын ауылшаруашылық аймақтары үшін дәстүрлі өндіріс әдісіне, оның мемлекеттілігі қалыптасу кезеңіндегі қазақ қоғамының дамуындағы экзогендік және эндогендік факторлар проблемасына бейімділік дәрежесінің эволюциясын байқауға болады. Бұл құбылыстар XIV-XVI ғасырлар кезеңіне сәйкес келеді. Осылайша, отырықшы және көшпелі компоненттердің өзара әсері ресми актілік дереккөздерде (жарлықтарға) көрініс тапты, өйткені «барлық шығыс халықтарында тарихтың басынан бастап олардың бір бөлігінің отырықшылығы мен екінші бөлігінің жалғасып келе жатқан көшпелілігі арасындағы жалпы арақатынасты байқауға болады» (Karataev, 2020:28).

Қазақ хандары мен сұлтандары берген жарлықтардың мұрағаттармен мен қолжазба қорларында іздеу керек, өйткені мұндай құжаттар бар болуы әбден мүмкін. Сухайла «Имамкулихан-наме» дерегінде, «қазақ ханы Тұрсын-Мұхаммед XVII ғасырдың басында Ташкентте өз монетасын жасап, баж бен хараджды халықтан жинады, яғни ол егеменді жоғарғы билеуші болды». Басқа қазақ хандары мен сұлтандары Сырдария маңындағы қалаларда осындай құқықтарға ие болды, яғни «олардың кеңселерінен әртүрлі сипаттағы құжаттар шығуы керек еді» деген мәлімет айтылады. (Karibaev, Maidanali, Bizhanova, Koshymova, Noyanov, 2019:18). Олардың қатарында жарлықтарда да болатынына күмән жоқ, өйткені әлеуметтікэкономикалық үдерістері сабақтастығы ұқсас актілік дереккөздерінің пайда болуына себеп болды. Осылайша, хан жарлықтарын зерттеу қазіргі заманғы деректанудың перспективалы бағыты болып табылады.

Мақ̆ала АРО8956286 - «Алтын Орда мен Алтын Ордадан кейінгі мемлекеттердің хан жарлықтары мен хаттарын іздеу (эвристика) және сыныптау» жоба тақырыббы аясында жарияланды.

\section{Әдебиеттер}

Абусеитова М.Х., Баранова Ю.Г. (2001) Письменные источники по истории и культуре Казахстана и Центральной Азии в XIII-XVIII вв. (биобиблиографические обзоры). Алматы: Дайк-пресс. 344 б.

Абусеитова M.X. (2020) Қазақстанның орта ғасыр тарихы хрестоматиясы (VI-XIX ғғ.). - Алматы: Шығыс пен Батыс.

Aksanov A. (2017) The Kazan Khanate.The History of the Tatars since ancient times. In Seven Volumes. Volume 4. Tatar States (15-18th Centuries). Kazan: Sh. Marjani Institute of History, English translation, pp.146-150

A. Melek Özyetgin (1996) Altın Ordu, Kırım ve Kazan sahasına ait Yarlık ve Bitiklerin Dil ve Üslûp incelemesi. Ankara.

Бартольд В.В. (1904) Отчет о командировке в Туркестан. ЗВО ИРАО. СПб. Т. 15, вып. 2-3. 264-275 бб.

Григорьев А.П. (2004) Сборник ханских ярлыков русским митрополитам. СПб.

Karataev O.K. (2020) About ancient political, administrative titles: shanyuy, tarkhan, buyuruk. Bulletin of history // ҚазҰУ хабаршысы. Тарих сериясы. №4 (99). Алматы: Қазақ университеті. 21-32 бб.

Karibaev B., Maidanali Z., Bizhanova M., Koshymova A., Noyanov Y. (2019) New methodological approaches to the study of political history of the Golden Horde in the 13th-16thCenturies. Codrul Cosminului, 25 (1). pp. 7-30.

Кушкумбаев А.К. (2020) Орды в политической истории Джучиева улуса (источники и историография). Алматы: Шығыс пен Батыс. 160 с. 
Kumekov B.E., Kartova Z.K. (2019) The source study analysis and classification of the tarkhan type khan yarlyks. ҚазҰУ хабаршысы.Тарих сериясы, Қазақ университеті,Т. 92, № 1, 17-23 бб.

Kurat N. Akdes. (2001) Topkapı Sarayı Muzesi arşivindeki Altın Orda, Kırım ve Turkistan hanlarına ait yarlık ve bitikler. İstanbul.

Материалы по истории казахских ханств XV-XVIII вв. (извлечения из персидских и тюркских сочинений) (1969). Алматы: Наука.

Nasan Bayar. (2014) A discourse of civilization/culture and nation/ethnicity from the perspective of inner Mongolia, China. Journal Asian Ethnicity,Volume 15, , Issue 4: Mongolia: Civilization, Nationality, and Ethnicity, pp. 439-457

Радлов В.В. (1888) Ярлыки Тохтамыша и Темир-Кутлука. ЗВО(И)РАО, Т. 3. Вып. 1-2. - СПб. 1-40 бб.

Pochekaev R. (2019) Pretended Suzerainty: Moscow Tsars and Kazakh Khans (According to Russian-Language Diplomatic Documents of the End of 16th - Beginning of 18th Centuries).

Почекаев Р.Ю. (2004) Ярлыки ханов Золотой Орды как источник по истории права. Кодексинфо № 1-2. М.,134-145 бб.

Усманов М.А. (1979) Термин «ярлык» и вопросы классификации официальных актов ханств Джучиева Улуса. Актовое источниковедение. М., 218-244 бб.

\section{References}

Abuseitova M.H, Baranova Ju.G. (2001) Pis'mennye istochniki po istorii i kul'ture Kazahstana i Central'noj Azii v XIII-XVIII vv. (biobibliograficheskie obzory) [Written sources on the history and culture of Kazakhstan and Central Asia in the XIII-XVIII centuries. (biobibliographic reviews)] Almaty: Dyke-press.

Abuseitova M.H. (2020) Qazaqstannyy orta ğasyr tarıhy hrestomatijasy (VI-XIX) [Anthology of medieval history of Kazakhstan (VI-XIX)] Almaty: East and West 344 p.

Aksanov A. (2017) [The Kazan Khanate.The History of the Tatars since ancient times] In Seven Volumes. Volume 4. Tatar States (15-18th Centuries). Kazan: Sh. Marjani Institute of History, English translation, pp.146-150.

A. Melek Özyetgin (1996) Altın Ordu, Kırım ve Kazan sahasına ait Yarlık ve Bitiklerin Dil ve Üslûp incelemesi [Golden Horde, Crimea and Kazan field of Yarlik and Bitiks language and style analysis] Ankara.

Bartol'd V.V. (1904) Otchet o komandirovke v Turkestan [Report on a business trip to Turkestan] ZVO IRAO. SPb. Vol. 15, issue 2-3. 264-275 pp.

Grigorev A.P. (2004) Sbornik hanskih jarlykov russkim mitropolitam [Collection of Khan's labels to Russian Metropolitans] St. Petersburg.

Karataev O.K. (2020) [About ancient political, administrative titles: shanyuy, tarkhan, buyuruk. Bulletin of history] Bulletin of Kaznu.History series, Kazakh University. №4 (99) 21-32 pp.

Karibaev B., Maidanali Z., Bizhanova M., Koshymova A., Noyanov Y. (2019) [New methodological approaches to the study of political history of the Golden Horde in the 13th-16 $6^{\text {th }}$ Centuries] Codrul Cosminului, 25 (1) 7-30pp.

Kushkumbaev A.K. (2020) Ordy v politicheskoj istorii Dzhuchieva ulusa (istochniki i istoriografija) [The Hordes in the Political History of the Juchi Ulus (sources and historiography).] Almaty: Almaty: East and West $160 \mathrm{p}$.

Kumekov B.E., Kartova Z.K. (2019) [The source study analysis and classification of the tarkhan type khan yarlyks] Bulletin of Kaznu.History series, Kazakh University, Vol. 92, No. 1, 17-23 pp.

Kurat N. Akdes. (2001) Topkapı Sarayı Muzesi arşivindeki Altın Orda, Kırım ve Turkistan hanlarına ait yarlık ve bitikler [Golden Horde, Crimea and Turkistan Khans in the Palace Museum archive] İstanbul.

Materialy po istorii kazahskih hanstv XV-XVIII vv. (izvlechenija iz persidskih i tjurkskih sochinenij) [Materials on the history of the Kazakh khanates of the XV-XVIII centuries. (extracts from Persian and Turkic writings)] (1969). Almaty: Science.

Nasan Bayar. (2014) [A discourse of civilization/culture and nation/ethnicity from the perspective of inner Mongolia, China] Journal Asian Ethnicity,Volume 15, , Issue 4: Mongolia: Civilization, Nationality, and Ethnicity, pp. 439-457

Radlov V.V. (1888) Jarlyki Tohtamysha i Temir-Kutluka [Labels of Tokhtamysh and Temir-Kutluk] ZVO(I)RAO, T. 3, vyp. 1-2.- $\mathrm{SPb} .1-40 \mathrm{pp}$.

Pochekaev R. (2019) [Pretended Suzerainty: Moscow Tsars and Kazakh Khans] (According to Russian-Language Diplomatic Documents of the End of 16th - Beginning of 18th Centuries).

Pochekaev R.Ju. (2004) Jarlyki hanov Zolotoj Ordy kak istochnik po istorii prava [Labels of the Khans of the Golden Horde as a source on the history of law] Kodeksinfo № 1-2., M.,134-145 pp.

Usmanov M.A. (1979) Termin «jarlyk» i voprosy klassifikacii oficial'nyh aktov hanstv Dzhuchieva Ulusa [The term "label” and issues of classification of official acts of the khanates of the Juchi Ulus] Act Source Studies M., 218-244 pp. 